\title{
Hydrocephalus after aneurysmal subarachnoid hemorrhage: Epidemiology, Pathogenesis, Diagnosis, and Management
}

\author{
Yu-Chang Wang ${ }^{1,2,3, \dagger}$, Xiao-Qiang Wang ${ }^{4, \dagger}$, Chang-Wu Tan ${ }^{1,2,3}$, Chuan-Sen Wang ${ }^{1,2,3}$, \\ Zhi Tang ${ }^{5}$, Zhi-Ping Zhang ${ }^{1,2,3}$, Jing-Ping Liu ${ }^{1,2,3}$, Ge-Lei Xiao ${ }^{1,2,3, *}$
}

\author{
${ }^{1}$ Department of Neurosurgery, Xiangya \\ Hospital, Central South University, \\ Changsha, Hunan 410008 , P. R. China \\ ${ }^{2}$ Diagnosis and Treatment Center for \\ Hydrocephalus, Xiangya Hospital, \\ Central South University, Changsha, \\ Hunan 410008, P. R. China \\ ${ }^{3}$ National Clinical Research Center for \\ Geriatric Disorders, Xiangya Hospital, \\ Central South University, Changsha, \\ Hunan 410008, P. R. China \\ ${ }^{4}$ Pediatric neurological disease center, \\ Xinhua Hospital, Shanghai Jiaotong \\ University School of Medicine, Shanghai, \\ 200092, P. R. China \\ ${ }^{5}$ Department of Neurosurgery, Hunan \\ Cancer Hospital and the Affiliated \\ Cancer Hospital of Xiangya School of \\ Medicine, Central South University, \\ Changsha, Hunan 410013, P. R. China
}

\section{*Correspondence \\ xiaogelei@csu.edu.cn \\ (Ge-Lei Xiao) \\ $\dagger$ These authors contributed equally.}

\begin{abstract}
Hydrocephalus is one of the most common complications of aneurysmal subarachnoid hemorrhage (aSAH), which seriously affects the quality of life and shortens the survival time of affected patients. By reviewing the recent studies on the risk factors of aSAHassociated hydrocephalus, we aimed to explicitly present the pathogenesis of acute and chronic hydrocephalus after aSAH and make a comprehensive list of the associated risk factors of aSAH-associated hydrocephalus and shunt-dependent hydrocephalus. It would help us to better explain the occurrence of hydrocephalus after aSAH, especially hydrocephalus caused by inflammation after bleeding. Many studies have recently suggested that high mobility group box 1 may be an early upstream promoter of inflammatory response after aSAH, which also provides important ideas for us to look for potential drug treatments. The surgery, such as external ventricular drain and lumbar drainage, is the most common and effective treatment. Yet, there are often complications, such as rebleeding and intracranial infection, and the optimal timing of intervention is controversial. Besides, this is also a systematic review of the recent advances in epidemiology, pathogenesis, diagnosis, and management of aSAHassociated hydrocephalus.
\end{abstract}

\section{Keywords}

Aneurysmal subarachnoid hemorrhage; Hydrocephalus; Pathogenesis; Therapeutic development; Management

\section{Introduction}

Subarachnoid hemorrhage (SAH) is a severe form of cerebrovascular disease, with a mortality rate of $40-60 \%$ and an incidence of $8-20 / 10,000$ [1-3]. It is mainly consecutive to aneurysm rupture. Hydrocephalus is one of the most common complications of aneurysmal subarachnoid hemorrhage (aSAH) [4]. It can cause injury to the central nervous system including impairment of cognition abilities [5]. Most studies have shown that acute hydrocephalus is mainly caused by an obstruction in the cerebrospinal fluid (CSF) circulation pathway whereas, an abnormal secretion and reabsorption of the CSF are the most likely causes of chronic hydrocephalus $[6,7]$.

In recent years, the pathogenesis of aSAH has been widely studied $[8,9]$. Inflammatory reaction plays an essential role in the pathogenesis of aSAH [10]. Many new targets, such as aquaporin-1, aquaporin-4 and toll-like receptor 4 (TLR-4), can be used for the non-surgical treatment of patients [10-12]. With the involvement of physics and artificial intelligence in medicine, there is a great convenience for early detection and treatment, many new diagnostic and predictive hydrocephalus models that are developed and were used on a small scale have become more popularized [13]. In recent years, the risk factors for shunt-dependent hydrocephalus (SDHC) in patients with aSAH with subarachnoid hemorrhage have been the topic of considerable debate, with yet no consensus to date $[14,15]$. Shunting is currently the most widely used surgical treatment for hydrocephalus, but there are often complications, and the optimal timing of intervention is controversial [2, $16,17]$. Surprisingly, it has been found in one survey that neurosurgeons in some areas used the opposite approach to safety (details in 5.2 Surgical treatment) $[18,19]$.

This paper reviews recent studies on the risk factors of aSAH-associated hydrocephalus $[5,20]$ with the aim to attempts to summarize and clarify the pathogenesis, diagnosis, and management of acute and chronic hydrocephalus consecutive to aSAH [21, 22]. We also aim to help health care workers in the early and active treatment and management and improve the prognosis of aSAH associated hydrocephalus patients. 
TA B L E 1. Ratio of SAH complicated with hydrocephalus.

\begin{tabular}{lccc}
\hline Study & No. of SAH patients & No. of SAH/hydrocephalus patients & Ratio \\
\hline Boswell et al. 2013 [23] & 30 & 14 & $46.7 \%$ \\
\hline Sprenker et al. 2015 [24] & 51 & 18 & $35.3 \%$ \\
\hline Konczalla et al. 2015 [25] & 173 & 46 & $26.6 \%$ \\
\hline Walcott et al. 2015 [26] & 138 & 5 & $3.6 \%$ \\
\hline Coelho et al. 2016 [27] & 65 & 14 & $22.6 \%$ \\
\hline
\end{tabular}

Abbreviations: $S A H=$ subarachnoid hemorrhage; No. of SAH patients $=$ Number of subarachnoid hemorrhage patients; No. of SAH/hydrocephalus patients = Number of hydrocephalus after subarachnoid hemorrhage patients.

\section{Epidemiology}

\subsection{Incidence}

According to different backgrounds and clinical conditions, the incidence of hydrocephalus after aSAH ranged from $3.6 \%$ to $46.7 \%$ [23-27] (Table 1). However, this is not a strict incidence estimate, as the entire population has not been screened. Acute and chronic hydrocephalus occurs in about $20 \%$ and $10 \%$ of patients with aSAH, respectively $[2,3,28]$. Acute hydrocephalus occurs within 3 days after the bleeding, subacute within 14 days, and chronic hydrocephalus occurs after 14 days [29]. Chronic hydrocephalus, commonly defined as shuntdependent hydrocephalus, affects $6-37 \%$ of patients with SAH [30]. The 1-year and 5-year survival rates for shunts are 57 and $37 \%$, respectively, about $8-10 \%$ of shunts becoming infected and requiring lengthy hospitalization [31]. The prevalence of hydrocephalus is much higher in Africa and South America than in other continents, with the incidence of hydrocephalus among children in Africa (104.0/100,000) being twice as high as in North America (55.6/100,000) [28, 32].

\subsection{Risk factors}

Although the occurrence of hydrocephalus after aSAH has been deeply studied and some preventive measures have been well taken, its potential risk factors are still uncertain [33]. To help neurosurgeons better manage aSAH patients, and to further facilitate our understanding of the risk factors for hydrocephalus after subarachnoid hemorrhage hydrocephalus, scientists have conducted extensive studies regarding the risk factors [5, 34].

In recent years, the risk factors for subarachnoid hemorrhage SDHC in aneurysms have become a hot topic [35]. Although in some studies women had a higher dependency to shunt [35-38], most have shown no significant gender differences [20, 35, 36, 39]. Bae et al. have shown a higher incidence of chronic hydrocephalus in people over 60 years old [36], and more studies show that the older you get, the worse the clinical outcome with more complications [14, 34, 40-43]. But Virta et al. recently reported that getting older did not make the outcome worse. However, we still believe that more care should be given to patients over 60 years old [44].

The Hunt-Hess [20, 36, 37, 41, 45] and Glasgow coma scales (GCS) [5] were used to assess the risk factors in many studies. The Hunt-Hess scale is widely used to assess patients with ruptured aneurysms [41]. Also, the High Fisher grade [35, 36], increasing failure risk index [37], higher World Federation of Neurological Surgeons grade $[14,15]$ are independent risk factors. García et al. proposed, for the first time, the use of a modified Graeb score, which maintains the simplicity of the qualitative score while increasing the assessment of acute hydrocephalus, which may improve the overall predictive power of SDHC [46].

Many studies have found that acute hydrocephalus [34, 35, 41, 42, 45, 47] predicts shunt-dependent hydrocephalus, while others have found no significant correlation between acute hydrocephalus and the need for shunt [39]. The presence of intraventricular hemorrhage (IVH) [34, 36, 45, 48-51] is significantly associated with the need for a shunt in patients with aSAH, in both univariate and multivariate analyses. IVH after aSAH is a common cause of acute hydrocephalus and often requires an external ventricular drain (EVD) treatment [52]. And many studies considered EVD placement [34, 47, 50, 53, 54] as the strongest predictor of acceptance after aSAH. How this acute hydrocephalus changes to chronic communicating hydrocephalus after aSAH remains to be elucidated. However, Savarra et al. suggested that there is no significant difference between EVD and SDHC [39]. Besides, many studies have analyzed a large number of clinical data and concluded that vasospasm [3, 14, 38], cerebral infarction [15], and meningitis [47] are closely associated with SDHC after aSAH.

Currently, the treatment of aneurysms (e.g., microsurgical clipping and intravascular coiling) remains controversial because of the risk factor for SDHC [55]. Park et al. reported that microsurgery clipping leads to a higher incidence of chronic hydrocephalus [56]. They hypothesized that intraoperative manipulation of small blood vessels would interfere with CSF homeostasis and induce vasospasm. However, other studies have found that there is no significant difference in the incidence of SDHC between the two [45, 53].

It is essential for medical personnel to identify the factors that increase shunt dependency and eliminate or mitigate reversible factors that put patients with aSAH at risk of SDHC. Also, identifying predictive variables and patients at risk for SDHC can prevent increased neurological morbidity, improving functional outcomes and quality of life, and prevent a prolonged hospital stay associated with chronic hydrocephalus [52] (Table 2). 
TA B L E 2. Risk factors for shunt-dependent hydrocephalus after aneurysms subarachnoid hemorrhage.

$\begin{array}{ll}\text { Type } & \text { The risk factors } \\ \text { Patient-related } & \text { (1) increasing age (2) female gender, (3) preexisting hypertension } \\ \text { Disease-related } & \begin{array}{l}\text { (4) Hunt-Hess grading } \geq 3,(5) \text { poor post subarachnoid shunt score, (6) GCS score <8, (7) poor modified } \\ \text { Graeb scale, (8) high Fisher grade, (9) vasospasm, (10) cerebral infarction, (11) meningitis, (12) fever, } \\ \text { (13) infection }\end{array} \\ \text { Treatment-related } & \begin{array}{l}\text { (14) endovascular aneurysm treatment, (15) microsurgical clipping, (16) ventriculostomy, (17) EVD } \\ \text { placement, (18) rapid weaning, (19) lack of CSF shunt }\end{array}\end{array}$

Abbreviations: $G C S=$ Glasgow coma scales; $E V D=$ external ventricular drain; $C S F=$ cerebrospinal fluid.

\section{Pathogenesis}

After aSAH, the blood mixes with the CSF and diffuses in the subarachnoid space (SAS) [9]. Blood and hemoglobin degradation products can be directly introduced into SAS to damage the neurons [57]. Many inflammatory mediators (IL1 , IL-6, and tumor necrosis factor- $\beta$ (TNF- $\beta$ )) are released into the CSF along with neutrophil and exacerbate the neuronal damage $[15,58]$. Therefore, various blood products entering the CSF after subarachnoid hemorrhage may cause damage to SAS and the brain parenchyma [8].

Although the exact molecular mechanism behind the pathophysiology in aSAH remains elusive, most studies show that acute hydrocephalus is mainly caused by an obstruction in the CSF flow, whereas an abnormal secretion and/or resorption of CSF are more likely the causes that lead to chronic hydrocephalus [9]. A better understanding of hydrocephalus' pathogenesis after aSAH is important to the development of clinical treatment (Fig. 1).

\subsection{Acute hydrocephalus}

Acute hydrocephalus causes early brain injury, which is usually considered a non-communicating (or obstructive) type, mainly due to the narrowing in the ventricles and the cerebral aqueduct or the blockage by blood clots that prevent CSF from flowing out of the cranium [57,59].

It has been demonstrated in animal models that the flow of CSF after SAH is obstructed [60]. The obstruction mechanism seems to be widely recognized in acute hydrocephalus but the pathophysiology mechanisms are still unclear. Many have been conducted to unveil the mechanism behind the pathophysiology of hydrocephalus. The deposition of fibrin in the perivascular space after SAH may play an important role [61]. Golanov et al.'s results suggest that CSF obstruction may not be caused by thrombosis, and tissue factor III may participate in the regulation of CSF flow under normal conditions [62].

Recently, Close et al. reported a particular case that provided evidence of the rapid development of hydrocephalus with periventricular inflammation, without aqueduct stenosis [63]. In the case of aquaporin-4 dysfunction, such as in neuromyelitis optica, changes in the CSF absorption can lead to acute hydrocephalus through a non-blocking mechanism [64]. However, obstruction is not specific to acute hydrocephalus.

Blood from the SAS and subsequent hemoglobin degradation can trigger a cascade of inflammation, which is thought to be the critical biomolecular mechanism that causes acute hy- drocephalus by breaking down the blood-brain barrier (BBB) $[65,66]$. Inflammation may lead to scarring, which blocks the flow of CSF through the cerebral aqueduct, fourth ventricular outlet, basal cisterns, and arachnoid granulations [66]. Degradation products of red blood cells in SAS may lead to the accumulation of hemoglobin and its products (methemoglobin, heme), which activate the toll-like receptor 4 (TLR4) and trigger an inflammatory cascade reaction [65]. Hemin is associated with the release of redox-active iron, altering the balance between oxidants and antioxidants [67]. Redox-active iron depletes antioxidants such as nicotinamide adenine dinucleotide phosphate and glutathione, producing both superoxide and hydroxyl radicals as well as lipid peroxidation [67]. Ironinduced oxidative stress leads to decreased ciliary function, which may trigger hydrocephalus [68]. Previous experimental studies have shown that iron-induced inflammation is involved in hydrocephalus formation after acute hemorrhage [69]. Mahaney et al. found no elevated levels of several iron scavenger proteins in the CSF of newborns with post hemorrhagic hydrocephalus, suggesting that hydrocephalus is a disease condition that occurs when the endogenous iron scavenger mechanism fails [70]. Recently, Zhang et al. confirmed that a lower serum iron content $(13.1 \mathrm{mmol} / \mathrm{L})$ after aSAH is a predictor of acute hydrocephalus and adverse outcomes [71].

In 2015, Sokó et al. reported for the first time that elevated high mobility group protein B1 (HMGB1) protein levels in consecutive samples of CSF from SAH patients were associated with adverse neurological outcomes [72]. HMGB1 is a well-characterized prototypical protein of damage-associated molecular pattern molecules (DAMPs) [73]. When the blood enters SAS through a ruptured aneurysm, it causes an increase in intracranial pressure. Damaged or compressed central nervous system cells will release DAMPs [74]. The oozing blood and its degradation products also damage various cells in the surrounding area, releasing DAMPs [75]. The over-expression of the mediators (IL-1, IL-6, and TNF- $\beta$ ) and receptors (TLR$2 / 4$, receptors for advanced glycation end-products) activates the destruction and repair process [76]. Sun et al. reported data showing that HMGB1 translocations precede other cytokine increase, HMGB1 may be an early upstream promoter of inflammatory response after SAH. So we can speculate that HMGB1 plays a vital role in the development of acute hydrocephalus [73].

The choroid plexus epithelium (CPE) secretes more CSF than other epithelial cells and acts as a blood-CSF barrier, introducing immune cells into the central nervous system [77]. Karimy et al.'s mouse model of post hemorrhagic hydro- 


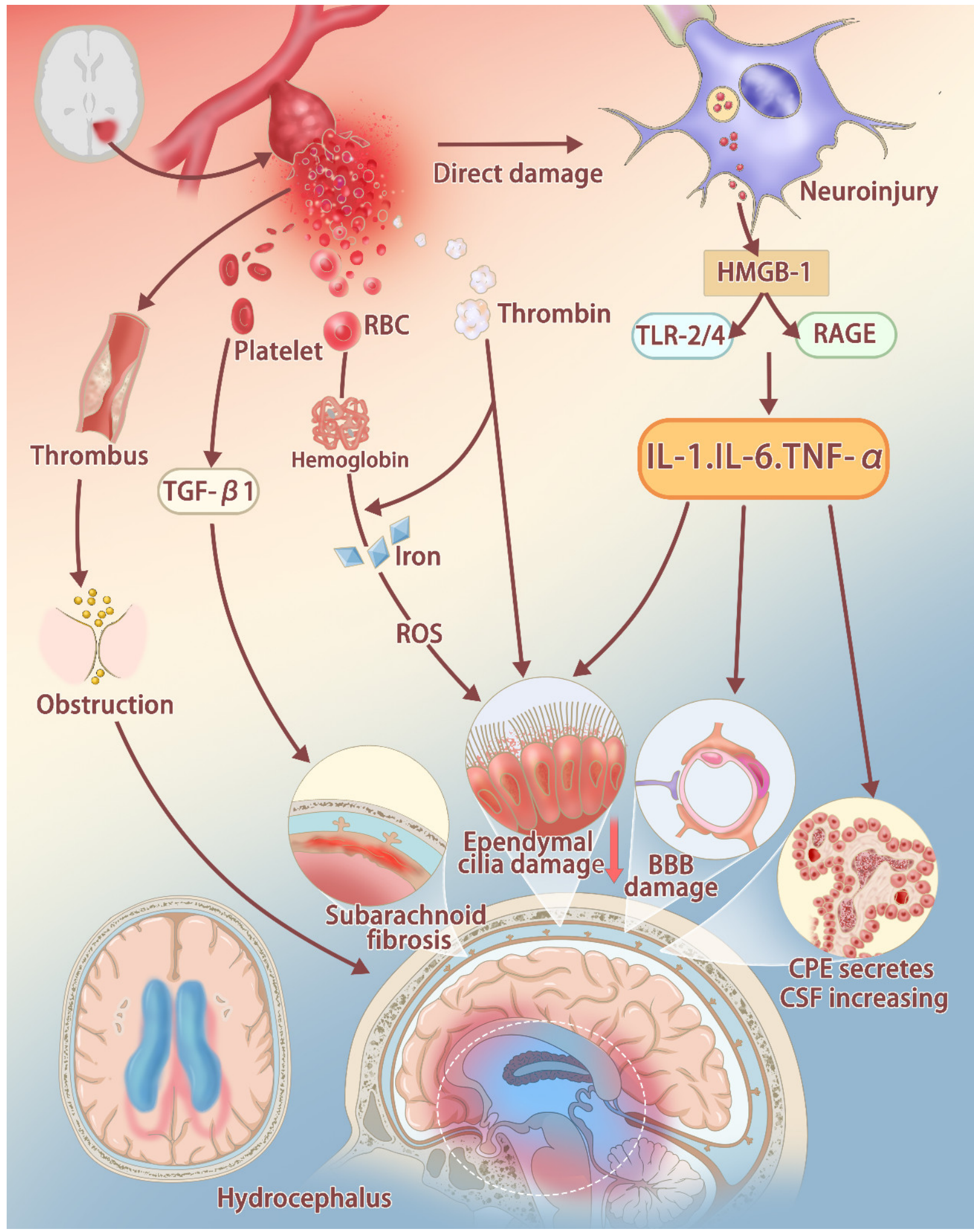

F I G U R E 1. The formation mechanism of hydrocephalus after aSAH. Numerous studies have reported direct damage and compression of central nervous system cells when blood enters the subarachnoid space through a ruptured aneurysm, extravasated blood and its degradation products can also damage various cells in adjacent regions and trigger inflammatory cascades that block circulation through a complex series of processes, with the CPE secreting more brain crest fluid, the fibrosis of CSF affects the absorption of CSF and promotes the development of hydrocephalus. Many studies have recently suggested that HMGB1 may be an early upstream promoter of inflammatory response after SAH. Abbreviations: HMGB1 = high mobility group protein B1; RAGE = receptors for advanced glycation end products; IL-1 = Interleukin 1; IL-6 = Interleukin 6; TNF- $\alpha=$ tumor necrosis factor $\alpha$; $\mathrm{CPE}=$ choroid plexus epithelium; $\mathrm{CSF}=$ cerebrospinal fluid; $\mathrm{CPE}=$ choroid plexus epithelium; TGF- $\beta 1=$ transforming growth factor- $\beta 1$; TLR $4=$ Toll-like receptor 4 ; $\mathrm{ROS}=$ reactive oxygen species; $\mathrm{RBC}=$ red blood cell. 
cephalus (PHH) showed that IVH caused a threefold increase in TLR-4 and NF- $\kappa$ B-dependent inflammatory responses in the associated CPE in bumetanide-sensitive CSF secretion [78]. The data revealed the role of previously unrecognized CSF overproduction in the pathogenesis of $\mathrm{PHH}$ and demonstrate the new role of TLRs in regulating the brain environment. Moreover, high levels of circulating cytokines, such as IL1 , IL-6, and IL-18, transforming growth factor $-\beta 1 / 2$ (TGF$\beta 1 / 2$ ), and TNF- $\alpha$ were detected in acute hydrocephalus after aSAH [33, 79-81].

\subsection{Chronic hydrocephalus}

In the end, some acute hydrocephalus after aSAH will evolve into chronic communicating hydrocephalus [22]. There is considerable evidence in the fibrotic pathway that chronic hydrocephalus is of "communication" type because of the fibrotic and adhesion of pia mater and arachnoid granules [38].

As discussed above, inflammation is strongly associated with acute hydrocephalus after aSAH, but its role in chronic hydrocephalus is equally significant [39]. Inflammation is related to the pathogenesis of some types of hydrocephalus, especially with fibrotic arachnoiditis, meningeal fibrosis, and subependymal gliosis [78]. Wessell et al. showed that persistent systemic inflammation following aneurysmal subarachnoid hemorrhage was associated with SDHC and predicted its occurrence [82]. Chaudhry et al. first reported a significant increase in serum IL-10 levels in SAH patients with chronic hydrocephalus on Day 7 [83]. IL-10 is an essential antiinflammatory cytokine secreted by almost all immune cells [84]. Elevated levels of IL-10 are usually associated with elevated pro-inflammatory cytokines [85]. Therefore, the significant increase of IL-10 after SAH may reflect the up-regulation of inflammatory response and immunosuppression induced by SAH. A high serum level of IL-10 predicts infection and poor prognosis after SAH [85].

TGF $\beta 1$, Vascular endothelial growth factor (VEGF), and hepatocyte growth factor (HGF) play a vital role in the pathogenesis of chronic hydrocephalus after aSAH [86, 87]. TGF $\beta 1$ is a fibrogenic molecule. There is evidence that subarachnoid fibrosis may be the cause of subarachnoid edema [88, 89]. High levels of TGF $\beta 1$ in CSF of patients with subarachnoid hemorrhage increases the risk of chronic hydrocephalus $[90,91]$. Studies have shown that the core proteoglycan can attenuate chronic hydrocephalus by inhibiting the TGF $\beta 1 / \mathrm{Smad} / \mathrm{CTGF}$ (connective tissue growth factor) pathway in a rat subarachnoid hemorrhage model [90, 92]. Tan et al. also demonstrated that cannabinoid receptor two agonists inhibit the fibrosis of the ventricles and reduce hydrocephalus after IVH by inhibiting the action of TGF $\beta 1$ [93]. After subarachnoid hemorrhage, Chen et al. stated that transplantation of human umbilical cord-derived MSCs (hUC-MSCs) into the brain's ventricles significantly reduces chronic hydrocephalus, inflammation, and behavioral disorders [92]. The transplantation of hUC-MSCs after SAH may play a beneficial role, possibly by inhibiting the TGF- $\beta 1 / \mathrm{Smad} 2 / 3$ signaling pathway [92].

VEGF levels rise significantly in hydrocephalus patients and rabbit models, which is thought to be a result of inflamma- tion in the brain. VEGF inhibits the BBB by reducing the expression of occluding and tight junction proteins claudin- 5 and promoting vascular permeability [94]. Inhibition of VEGF signaling lowers vascular permeability and causes deposition of fibrin in the choroid plexus [95, 96].

Not only VEGF, but HGF is also worthy of attention in the development of hydrocephalus. Naureen et al. reported significantly higher VEGF and HGF in delayed hydrocephalus than neonatal hemorrhage without hydrocephalus [97]. In adult rats with chronic hydrocephalus after $\mathrm{SAH}$, the expression of VEGF and HGF increases significantly [98]. Recently, Feng et al. reported that urokinase-type plasminogen activator (uPA), by promoting the release and activation of HGF, effectively inhibits subarachnoid fibrosis in rats and inhibits the development of communicating hydrocephalus, which may further regulate TGF- $\beta 1$ expression in CSF [99].

\section{Diagnosis}

\subsection{Clinical presentation}

The etiology and dynamics of hydrocephalus are still unclear [100]. Acute, rapidly developing hydrocephalus is a life-threatening disease that requires immediate neurosurgical treatment [59]. An acute increase in intracranial pressure can lead to a temporal lobe herniation through the transtentorial notch and/or cerebellar protrusion into the foramen magnum [60]. However, acute hydrocephalus after aSAH has no specific clinical symptoms and signs, and the incidence of acute hydrocephalus is parallel to the clinical grade of SAH (according to Hunt-Hess standards) [101]. So imaging data are often needed for the diagnosis.

In contrast, chronic hydrocephalus usually has no symptoms or fewer such as headaches, dizziness, impaired vision, and attention [102]. Other typical symptoms are morning vomiting and papillary edema of the optic nerve seen in the ophthalmologic examination, which is due to a gradual increase in intracranial pressure [103].

\subsection{Imaging examination}

Different methods have been used to diagnose hydrocephalus, including physical, neurological, and imaging tests [104, 105]. Imaging studies in particular have shown high accuracy for hydrocephalus [101]. Three main types of imaging are performed for hydrocephalus, including ultrasound, computed tomography (CT), and MRI.

For patients with acute hydrocephalus and clinical manifestations of acute loss of consciousness, CT is the leading examination method because of the short examination time and thus presenting quick results; otherwise, the alternative examination is MRI [106]. If acute hydrocephalus is clinically suspected, a fluid-attenuated inversion recovery scan is sufficient to exclude the impairment of CSF circulation, and both detection and exclusion of CSF extravasation are indirect signs of increased intracranial pressure [104]. For obstructive hydrocephalus, any intracranial tumor of a particular size may block the CSF pathway, theoretically [104]. So different sites of MRI diagnosis need to be distinct. For example, about $60 \%$ of colloid cysts show high signal on $\mathrm{T} 1$-weighted $(\mathrm{T} 1 * \mathrm{w})$ 
MRI scans [107]. In traffic hydrocephalus formed by aSAH, in the case of the slow development of hydrocephalus after hemorrhage, cerebral CT usually cannot detect blood residue. However, changes after hemorrhage can be detected on $\mathrm{T} 2{ }^{*} \mathrm{w}$ MRI scans for a much longer time [108].

Current guidelines recommend the use of the Evans Index (EI) as a radio diagnostic marker for hydrocephalus, which is based on electroencephalographic findings of hydrocephalus in children reported in the early 1940s [105]. The calculation is to divide the maximum width of the frontal horns by the maximum width of the frontal inner table [109]. EI $>0.30$ is considered to be an indicator of hydrocephalus, independent of age [110]. Subsequent CT studies confirmed the reliability of the diagnosis with EI [111]. Besides, the ventricular shuntrelated complications (SRC) index is also used [112]. The ventricular SRC index is estimated by the distance (measured from the medial side of the skull) between the Frontal Horn and the dual frontal diameter at the same level, which average measurement is thought to be 30 percent [40, 112].

Ionizing radiation increases the risk of tumors, especially in children with shunt hydrocephalus [113]. Ultrafast brain MRI (UFB-MRI) and transfrontal cranial ultrasound are recommended for children under six months [114]. Marchese et al. developed a new clinical pathway to not only reduce the overall radiation dose in children but also reduce the CT X-ray dose in hydrocephalus patients [115]. This pathway discourages unnecessary shunt series and reduces effective radiation dose by $51 \%$ [115].

So far, the MRI technique that can show CSF movement is the phase-contrast MR imaging [116]. The degree of aqueduct signal loss is thought to reflect the rate of pulsating CSF motion, which in turn depends on relative ventricular compliance and surface area [117]. Successful treatment can be achieved by understanding CSF flow patterns and restoring these flow patterns when under abnormal conditions [118]. The permeability of the endoscopic third ventriculostomy (ETV) was evaluated using a series of image parameters, including changes in ventricular size, flow gap signal intensity, and MR patency, using cine phase-contrast MR imaging [116].

\subsection{Artificial intelligence}

Artificial intelligence (AI) is gaining popularity in medicine, especially in medical image recognition, auxiliary diagnosis, medical robots, drug research and development, health management, and so on [119].

Machine learning algorithms help discover the contribution of nonlinear variables in complex environments, such as predicting tumor growth or identifying surgical candidates [120]. Based on transfer learning, Duan et al. established the AI diagnostic model of hydrocephalus by using CT images and diagnosed hydrocephalus by reading the CT images of the brain through analyzing the factors such as ventricular shape, volume, Evan Index, age, etc. [121].

During a hydrocephalus treatment, radiologists spend a lot of time manually segmenting CT images to assess [122]. The assessment of these segments is often highly subjected to intraobserver variability [123]. To improve this, Klimont et al. proposed the use of a U-Net convolutional neural network for automatic segmentation of brain CT scans [124].

\section{Treatment}

Researchers have been trying to develop non-surgical treatments for hydrocephalus. However, most non-surgical treatments remain in animal trials and have not yet entered clinical trials. Their goals are to prevent hydrocephalus or to find supplemental treatment to shunt [10]. There is no definitive treatment for hydrocephalus, and most patients use a silicone tube and valve system, in which the CSF is transferred from the ventricles to another part of the body [2]. However, shunt therapy is often associated with complications, especially obstruction and infection in infants, increasing morbidity and mortality, and the optimal timing of intervention is unknown [18].

\subsection{Non-surgical treatment}

As the mechanisms of hydrocephalus have been gradually unveiled in recent years, some experimental drugs, such as isosorbide, have been found to have potential effects in improving the prognosis of patients by controlling the production of CSF, diuresis, fibrinolysis of blood clots, or the control of subarachnoid fibrosis, and more importantly, results have been achieved in various animal trials [125]. Still, there is no specific drug treatment because of the lack of reliable clinical trials to demonstrate a sustained and convincing remediable effect and the current treatments are simply to relieve symptoms. Here are a few current advances in nonoperative treatment [126] (Table 3).

In the 1950s and early 1960s, when shunts were introduced, hydrocephalus was treated with drugs that reduced the production of CSF or dewatered the brain through diuresis, such as isosorbide. But isosorbide is an unpleasant substance that can lead minor vomiting, diarrhea and even failure to gain weight at the normal rate during isosorbide therapy, and this has further proven that thrombin is an essential factor in hydrocephalus after intracerebral hemorrhage as discussed previously [126, 127].

Aquaporin-1 and aquaporin-4 (AQP1 and AQP4) are involved in the pathogenesis of hydrocephalus [125]. Lon et al. Investigated the dynamic changes of AQP1 and AQP4 after SAH by injecting autologous blood into the cisterna magna of the rat to cause secondary hemorrhage [11]. AQP1 was involved in the production of CSF and the increase of AQP4 might be the compensatory regulation of re-absorption of ependymal CSF [128, 129]. Acetazolamide is a carbonic anhydrase inhibitor that has been reported to reduce cerebrospinal fluid production $[130,131]$. Its role in regulating AQP expression may be involved in the mechanism of reducing CSF production [132-134]. Early clinical trials have shown that acetazolamide combined with furosemide may have a therapeutic effect on hydrocephalus [135]. But in this study, the combination of acetazolamide and furosemide also showed a higher risk of hypercalciuria and even nephrocalcinosis. In other studies, the combination of acetazolamide and furosemide has been found to be ineffective in reducing shunt placement and is associated with increased neurological morbidity [136, 137]. 
T A B L E 3. Drug treatment of hydrocephalus in clinical practice.

\begin{tabular}{|c|c|c|c|c|}
\hline Drug & Method and dosag & Treatment object & Result & Country \\
\hline Cilostazol [42] & $\begin{array}{l}50 \text { or } 100 \mathrm{mg} / 2 \text { or } 3 \text { times per day orally } \\
\text { or enterally }\end{array}$ & $\begin{array}{l}87 \text { SAH patients with } \\
\text { SDHC }\end{array}$ & $\begin{array}{ll}\text { decreased } & \text { serum } \\
\text { tenascin-C level and } \\
\text { probability } \text { of SDHC } \\
\text { after SAH }\end{array}$ & Japan \\
\hline Isosorbide [127] & $\begin{array}{l}2 \mathrm{gm} / \mathrm{kg} \text { body weight at } 6 \text {-hour inter- } \\
\text { vals, } 2 \text { or } 2.5 \mathrm{gm} / \mathrm{kg} \text { every } 4 \text { hours orally }\end{array}$ & 60 hydrocephalic infants & $\begin{array}{l}67 \% \text { of patient with less } \\
\text { severe symptoms }\end{array}$ & England \\
\hline $\begin{array}{l}\text { Acetazolamide and } \\
\text { furosemide [135] }\end{array}$ & $\begin{array}{l}\text { Furosemide } 1 \mathrm{mg} / \mathrm{kg} \text { daily and acetazo- } \\
\text { lamide } 20 \mathrm{mg} / \mathrm{kg} \text { daily increasing daily } \\
\text { by } 10 \mathrm{mg} / \mathrm{kg} \text { up to } 100 \mathrm{mg} / \mathrm{kg} \text { daily } \\
\text { intravenously or by mouth }\end{array}$ & $\begin{array}{l}10 \text { post-hemorrhagic hy- } \\
\text { drocephalus infants }\end{array}$ & $\begin{array}{l}9 \text { infants avoided shunt- } \\
\text { ing }\end{array}$ & America \\
\hline $\begin{array}{l}\text { Acetazolamide and } \\
\text { furosemide [136] }\end{array}$ & $\begin{array}{l}\text { Acetazolamide }(100 \mathrm{mg} / \mathrm{kg} / \mathrm{d}) \text { and } \\
\text { furosemide }(1 \mathrm{mg} / \mathrm{kg} / \mathrm{d}) \text { orally }\end{array}$ & $\begin{array}{l}177 \text { infants who had ven- } \\
\text { tricular expansion fol- } \\
\text { lowing IVH }\end{array}$ & $\begin{array}{l}85 \%(72 / 85) \text { infants as- } \\
\text { signed drug therapy died } \\
\text { or disabled or impaired at } \\
1 \text { year compared }\end{array}$ & Worldwide \\
\hline $\begin{array}{l}\text { Acetazolamide and } \\
\text { furosemide [137] }\end{array}$ & $\begin{array}{l}\text { Acetazolamide }(100 \mathrm{mg} / \mathrm{kg} \text { daily }) \text { and } \\
\text { furosemide ( } 1 \mathrm{mg} / \mathrm{kg} \text { daily) orally }\end{array}$ & $\begin{array}{l}129 \text { infants who had ven- } \\
\text { tricular expansion fol- } \\
\text { lowing IVH }\end{array}$ & $\begin{array}{l}84 \%(52 / 62) \text { of infants } \\
\text { assigned drug therapy } \\
\text { died or disabled or } \\
\text { impaired at } 1 \text { year }\end{array}$ & Worldwide \\
\hline $\begin{array}{l}\text { Dexamethasone } \\
{[141]}\end{array}$ & $\begin{array}{l}0.4 \mathrm{mg} / \mathrm{kg} \text { per day to } 0.1 \mathrm{mg} / \mathrm{kg} \text { per day } \\
\text { intravenously for } 4 \text { weeks }\end{array}$ & $\begin{array}{l}43 \text { patients with tubercu- } \\
\text { lous meningitis }\end{array}$ & no significant difference & Vietnam \\
\hline Prednisolone [142] & $\begin{array}{l}2 \mathrm{mg} / \mathrm{kg} / \mathrm{day} \text { or } 4 \mathrm{mg} / \mathrm{kg} / \text { day for } 4 \\
\text { weeks }\end{array}$ & $\begin{array}{l}63 \text { children with tubercu- } \\
\text { lous meningitis }\end{array}$ & $\begin{array}{l}\text { higher risk of } \\
\text { hydrocephalus in the } \\
\text { high-dose group }\end{array}$ & India \\
\hline
\end{tabular}

Abbreviations: $S A H=$ subarachnoid hemorrhage; $C S F=$ cerebrospinal fluid; $S D H C=$ shunt-dependent hydrocephalus;

IVH = intraventricular hemorrhage.

Now acetazolamide is also not recommended for management of hydrocephalus [138]. Other drugs that target AQPs, such as erythropoietin, have shown good results in animal models of hydrocephalus [12, 139]. More clinical trials need to be done to make sure the efficacy and possible side effects of erythropoietin.

Inflammation in the SAS has been considered a starting factor for secondary brain injuries such as hydrocephalus, cerebral edema, and vasospasm [85]. It was also found that bacterial meningitis may cause marked changes in the size of the ventricle and increased brain ventricle size was associated with increased mortality [140]. As a classic antiinflammatory, cortisol does not show a significant therapeutic effect in hydrocephalus [141]. And even in another study, the use of high doses of prednisolone has shown potential of increasing the risk of hydrocephalus [142]. After aneurysmal subarachnoid hemorrhage, chronic hydrocephalus is associated with the induction of tenascin- $\mathrm{C}$, a matricellular protein that may be induced by inflammation [143, 144]. Nakatsuka et al. reviewed 87 cases of Fisher grade $3 \mathrm{SAH}$ patients with chronic SDHC and found that a higher dose of cilostazol could effectively inhibit the level of tenascin-C between day one and day twelve after $\mathrm{SAH}$, to prevent the development of chronic hydrocephalus [42]. However, due to the anti-inflammatory effect of cilostazole itself, it cannot be ruled out that cilostazole may have therapeutic effect through other mechanisms independent of tenascin-C $[145,146]$. The prevention of the development of chronic hydrocephalus is possible through eliminating unnecessary shunt surgery [42].

\subsection{Surgical treatment}

Non-surgical measures to improve the flow of CSF after aSAH have little effect on the recovery of intracranial pressure, and most patients ultimately require surgical treatment, such as EVD, lumbar drainage, CSF shunts, and ETV [18]. According to clinical guidelines, CSF drainage, such as EVD and lumbar drainage, is recommended to treat acute symptomatic hydrocephalus; EVD (Loe III; Gor B) is recommended for acute hydrocephalus with IVH in the third or fourth ventricle; lumbar drainage is recommended in cases without IVH and supratentorial Hernia (Loe IV; Gor C) [2, 16, 17$]$.

Permanent CSF shunt can take many forms. According to the part of the shunt, can be divided into subdural - peritoneal shunt: remove the CSF from epidural inferior vena to peritoneal cavity [147]; ventriculoperitoneal shunt (VPS) to transfer CSF from the brain to the peritoneal cavity (the potential gap between the abdominal wall and the abdominal organs) [148]. There are a few special shunt valves that deserve to be mentioned. The anti-siphon, which closes when the pressure inside the valve is inversely related to the ambient pressure to prevent excessive drainage. This would occur when the patient is sitting, standing, or rapidly changing position [149]; Antibiotic-impregnated can significantly reduce a patient's risk of infection [150]. 
It has been reported that the neurological function of patients with acute hydrocephalus can be improved by EVD [34]. Whether EVD surgery increases the risk of rebleeding and intracranial infection remains controversial [54, 151]. Hasan et al. prospectively studied 473 patients and reported that the rate of rebleeding within 12 days after onset of aSAH was significantly higher in patients with EVD (43\%) than in patients without $\operatorname{EVD}(15 \%, P=0.025)$ [55]. Besides, Zhu et al. argued in a systematic review that the use of antiplatelet and/or anticoagulant drugs in endovascular aneurysm treatment of ruptured aneurysms in patients with aSAH might increase the risk of EVD related bleeding [152].

The timing and strategy for stopping ventricular drainage remain controversial. Caption et al. surveyed 14 neurosurgical departments in Scandinavia concerning the management of EVD treatment in aSAH patients and found that $85 \%$ of respondents said they were unaware of international guidelines for EVD discontinuation in patients with hydrocephalus after aSAH [18]. In $74 \%$ of patients, the EVD discontinuation strategy was mainly based on the patient's clinical condition and drainage volume [18]. Besides, Chung et al. distributed information about EVD management practices to 72 critical care units in the United States and found that most organizations use a single primary management method of EVD, and the consensus is to continuously open EVD to allow CSF drainage in secure aneurysm patients, at the same time, adopt a gradual weaning strategy [19]. Surprisingly, the best available evidence suggests that the opposite approach is safe and reduces the period of ICU hospitalization [19].

Lumbar drainage is also an option [153-155]. However, large hematomas and obstructive hydrocephalus are contraindications [156]. A Study has reported high rates of non-functional lumbar cistern drainage and a variety of complications, but fortunately, there are usually no significant long-term sequelae [157]. Repeated lumbar puncture has also been shown to reduce the incidence of CSF infection in aSAH after vascular coiling [153].

ETV has been performed in pediatric patients over the past few decades with successful effects [158-160]. Besides, ventriculostomy is beneficial for patients with acute subarachnoid hemorrhage [161]. Routine ventriculostomy does not reduce the incidence of SDHC and should not be performed routinely [2]. However, ventriculostomy may increase the risk of rebleeding and meningitis/ventriculitis, which was reported to be associated with age and etiology $[162,163]$.

There is no established standard for an ideal EVD clamp test in non-traumatic subarachnoid hemorrhage patients before inserting a ventricular-peritoneal shunt [164]. Ascanio et al. found that VPS's surgical placement was associated with complications [165]. A large percentage of patients in this study were found to have passed the second and third EVD clamp tests without subsequent shunt insertion. These data support multi-clamp testing before shunt placement [165]. Besides, Akinduro et al.'s retrospective study of 489 patients with aSAH found that patients who had failed the first or subsequent EVD clamp tests had a lower risk of developing delayed hydrocephalus but ultimately required VPS [166]. Ilic et al. have shown that VPS placement using the ventriculostomy site does not significantly increase the risk of VPS-related infections or VPS-related bleeding [148].

Kamenova et al. [167] report that the incidence of bleeding events after VPS appears to be comparable in patients receiving low-dose acetylsalicylic acid (ASA) treatment and in patients not receiving ASA treatment. Al-Holou et al. found in a multicenter retrospective study that gastrostomy tube placement significantly increased the risk of VPS infection [168]. Zhang et al. reported that using a modified VPS to place a distal shunt catheter lateral to the hydrocephalus could reduce the possibility of reoperation due to the complications of catheter obstruction and infection [169] (Table 4).

\section{Prognosis}

The readmission rate is increasingly accepted as a quality indicator [170, 171]. Dasenbrock et al. reported that 3,387 patients had a 30-day readmission rate of $10.2 \%(n=346)$ and that hydrocephalus was one of the most common causes of readmission for SAH [172].

In recent years, the long-term prognosis of patients with aneurysmal subarachnoid hemorrhage has received increasing attention. In a retrospective study, Wang et al. found that more than $50 \%$ of patients with aSAH had a good functional prognosis after rehabilitation and hyperbaric oxygen therapy [173]. The degree of neurological impairment can predict a poor prognosis. Clinical follow-up after discharge has improved the understanding and treatment of late-onset hydrocephalus, according to a new study [22].

Early rehabilitation is useful in a range of acute neurological disorders, but it has not been established as part of the subarachnoid hemorrhage guidelines for the treatment of aneurysms [174]. This may be due in part to a fear of aggravation of the development of aSAH complications. In a prospective interventional study, Karic et al. found that early mobilization and rehabilitation after aSAH was safe and feasible [175]. The rapid improvement allows patients to be early and highly active without increasing neurosurgical complications [176]. Early recovery from each mobilization step within the first four days after repair can relieve cerebral vasospasm, reducing the risk of severe and clinical vasospasm by $30 \%$ [175].

Patients with aneurysmal subarachnoid hemorrhage hydrocephalus have significant cognitive deficits in attention function, short-term and long-term memory, concentration, and motor coordination, and are severely impaired in quality of life and emotion; it might have something to do with white matter being damaged in the subacute phase [177]. The presence of cognitive impairment in survivors requires the establishment of a multidisciplinary clinic for the long-term management of aSAH patients [21, 22].

\section{Conclusions}

This paper helps us to better understand the occurrence of hydrocephalus after aSAH, especially hydrocephalus caused by inflammation after bleeding, which deserves our attention. It also provides important grounds for potential drug treatments. We provided a more comprehensive risk factor analysis of SDHC and discussed in detail the potential mechanisms 
TA B L E 4. Surgical treatments and their results.

\begin{tabular}{|c|c|c|c|c|c|}
\hline Treatments & Years & Patients & Number & Results & References \\
\hline ETV & 2005 & $\begin{array}{l}\text { hydrocephalus in children less } \\
\text { than } 2 \text { years of age }\end{array}$ & 97 & $\begin{array}{l}66.6 \% \text { in post-hemorrhagic hydro- } \\
\text { cephalus }\end{array}$ & [162] \\
\hline ETV & 2006 & $\begin{array}{l}\text { tumor-induced obstructive hy- } \\
\text { drocephalus }\end{array}$ & 42 & success rate $68 \%$ & [161] \\
\hline $\begin{array}{lr}\text { EVD } & \text { catheters } \\
\text { impregnated } & \text { with } \\
\text { silver nanoparticles }\end{array}$ & 2008 & acute obstructive hydrocephalus & 19 & $\begin{array}{l}\text { no catheter-associated ventriculitis } \\
\text { (compared to } 5 / 20 \text { in control) }\end{array}$ & [151] \\
\hline LD & 2009 & ICP with TBI or SAH & $45+55$ & $45 \%$ died & [155] \\
\hline ETV & 2010 & hydrocephalus patients & 41 & $\begin{array}{l}\text { primary success rates } 75.8 \% \text {; sec- } \\
\text { ondary success rates } 55.6 \%\end{array}$ & [159] \\
\hline LD & 2011 & $\begin{array}{l}\text { increased intracranial pressure } \\
\text { secondary to aneurysm rupture }\end{array}$ & 6 & $\begin{array}{l}\text { ICP was reduced from } 30.2 \mathrm{mmHg} \\
\pm 6.7 \text { to } 9.7 \mathrm{mmHg} \pm 7.4\end{array}$ & [154] \\
\hline ETV or VPS & 2013 & $\begin{array}{l}\text { patients with INPH and a posi- } \\
\text { tive response to the tap test }\end{array}$ & 42 & $\begin{array}{l}\text { VPS group better improvement } \\
(\mathrm{ETV}=50 \%, \mathrm{VPS}=76.9 \%)\end{array}$ & [160] \\
\hline EVD or LD & 2014 & grade III aSAH & $76+72$ & $\mathrm{LD}$ is better than EVD & [163] \\
\hline $\begin{array}{l}\text { VPS with open distal } \\
\text { shunt catheter placement }\end{array}$ & 2015 & hydrocephalus & 5 & $\begin{array}{l}\text { reduce the necessity of repeat } \\
\text { surgery }\end{array}$ & [169] \\
\hline VPS & 2018 & $\begin{array}{l}\text { in infants with obstructive hy- } \\
\text { drocephalus }\end{array}$ & 27 & success rates $88.5 \%$ & [164] \\
\hline $\begin{array}{l}\text { ETV/choroid plexus cau- } \\
\text { terization }\end{array}$ & 2018 & $\begin{array}{l}\text { in infants with obstructive hy- } \\
\text { drocephalus }\end{array}$ & 22 & success rates $68.2 \%$ & [164] \\
\hline VPS & 2019 & patients with ICP & 28 & a revision rate of $11 \%$ & [149] \\
\hline EVD & 2020 & aSAH & 138 & $\begin{array}{l}31.9 \% \text { died or had withdrawal of } \\
\text { care during admission }\end{array}$ & [166] \\
\hline
\end{tabular}

Abbreviations: $E T V=$ endoscopic third ventriculostomy; $E V D=$ external ventricular drain; $L D=$ lumbar drainage; $I C P=$ intracranial hypertension; TBI = traumatic brain injuries; $S A H=$ subarachnoid hemorrhage; CSF = cerebrospinal fluid; $V P S=$ ventriculoperitoneal shunt; INPH =idiopathic normal pressure hydrocephalus; aSAH = aneurysms subarachnoid hemorrhage.

of hydrocephalus after aSAH. There is still a debate about the risk of serious complications from EVD surgery, such as the increased risk of aneurysm rebleeding and intracranial infection. Therefore, more evidence is needed. Hydrocephalus consecutive to aSAH is a pathology that cannot be ignored. We hope that our review will help healthcare professionals to understand the causes and mechanisms of hydrocephalus development and improve the patient's prognosis through early and active treatment and management.

\section{ABBREVIATIONS}

AI, artificial intelligence; AQP1 and AQP4, aquaporin1 and aquaporin-4; aSAH, aneurysmal subarachnoid hemorrhage; BBB, blood-brain barrier; BMSCs, bone marrow mesenchymal stem cells; CPE, choroid plexus epithelium; CSF, cerebrospinal fluid; CT, computed tomography; CTGF, connective tissue growth factor; DAMPs, damage-associated molecular pattern molecules; EI, Evans Index; ETV, endoscopic third ventriculostomy; EVD, external ventricular drain; GCS, Glasgow coma scales; HGF, hepatocyte growth factor; HMGB1, high mobility group protein B1; $\mathrm{IVH}$, intraventricular hemorrhage; $\mathrm{PHH}$, post hemorrhagic hydrocephalus; SAH, subarachnoid hemorrhage; SAS, subarachnoid space; SDHC, shunt-dependent hydrocephalus; SRC, shunt-related complications; TGF- $\beta 1 / 2$, transforming growth factor $-\beta 1 / 2$; TLR-4, toll-like receptor 4 ; TNF- $\beta$, tumor necrosis factor- $\beta$; uPA, urokinase-type plasminogen activator; VEGF, vascular endothelial growth factor; VPS, ventriculoperitoneal shunt's.

\section{AUTHOR CONTRIBUTIONS}

YCW and XQW collected the related paper. CWT, CSW, ZT and ZPZ drafted and revised the manuscript. JPL and GLX participated in the design of the review and helped to draft and revise the manuscript. All authors read and approved the final manuscript.

\section{ETHICS APPROVAL AND CONSENT TO PARTICIPATE}

There are no ethical/legal conflicts involved in the article. 


\section{ACKNOWLEDGMENT}

I would like to express my gratitude to all those who helped us during the writing of this manuscript and thanks to all the peer reviewers for their opinions and suggestions.

\section{FUNDING}

This work was supported by the Hunan Provincial Natural Science Foundation of China (No. 2019JJ50949) and a grant from the research projects of the Hunan Provincial Health Commission of China No. B2019187).

\section{CONFLICT OF INTEREST}

The authors declare no conflict of interest.

\section{CONSENT FOR PUBLICATIOR}

All authors have read and approved the content and agree to submit this manuscript for publication consideration to your journal.

\section{REFERENCES}

[1] Sarfo FS, Ovbiagele B, Matthew OA, Akpalu A, Wahab K, Obiako R, et al. Antecedent febrile illness and occurrence of stroke in West Africa: the SIREN study. Journal of the Neurological Sciences. 2020; 418: 117158.

[2] Connolly ES, Rabinstein AA, Carhuapoma JR, Derdeyn CP, Dion J, Higashida RT, et al. Guidelines for the management of aneurysmal subarachnoid hemorrhage: a guideline for healthcare professionals from the American Heart Association/American Stroke Association. Stroke. 2012; 43: 1711-1737.

[3] Vinas Rios JM, Sanchez-Aguilar M, Kretschmer T, Heinen C, Medina Govea FA, Jose Juan S, et al. Predictors of hydrocephalus as a complication of non-traumatic subarachnoid hemorrhage: a retrospective observational cohort study in 107 patients. Patient Safety in Surgery. 2018; 12: 13.

[4] Wang Y, Lin Y, Chuang M, Lee T, Tsai N, Cheng B, et al. Predictors and outcomes of shunt-dependent hydrocephalus in patients with aneurysmal sub-arachnoid hemorrhage. BMC Surgery. 2012; 12: 12.

[5] Hao X, Wei D. The risk factors of shunt-dependent hydrocephalus after subarachnoid space hemorrhage of intracranial aneurysms. Medicine. 2019; 98: e15970.

[6] Spina S, Laws SM. Insights into the pathogenesis of normal-pressure hydrocephalus. Neurology. 2019; 92: 933-934.

[7] Ban VS, El Ahmadieh TY, Aoun SG, Plitt AR, Lyon KA, Eddleman C, et al. Prediction of outcomes for ruptured aneurysm surgery. Stroke. 2019; 50: 595-601.

[8] Kooijman E, Nijboer CH, van Velthoven CTJ, Mol W, Dijkhuizen RM, Kesecioglu $\mathrm{J}$, et al. Long-term functional consequences and ongoing cerebral inflammation after subarachnoid hemorrhage in the rat. PLoS ONE. 2014; 9: e90584.

[9] Wang K, Tang S, Lee J, Jeng J, Lai D, Huang S, et al. Intrathecal lactate predicting hydrocephalus after aneurysmal subarachnoid hemorrhage. The Journal of Surgical Research. 2015; 199: 523-528.

[10] Xiong L, Sun L, Zhang Y, Peng J, Yan J, Liu X. Exosomes from bone marrow mesenchymal stem cells can alleviate early brain injury after subarachnoid hemorrhage through miRNA129-5p-HMGB1 pathway. Stem Cells and Development. 2020; 29: 212-221.

[11] Long C, Huang G, Du Q, Zhou L, Zhou J. The dynamic expression of aquaporins 1 and 4 in rats with hydrocephalus induced by subarachnoid haemorrhage. Folia Neuropathologica. 2019; 57: 182-195.

[12] Rizwan Siddiqui M, Attar F, Mohanty V, Kim KS, Shekhar Mayanil C, Tomita T. Erythropoietin-mediated activation of aquaporin-4 channel for the treatment of experimental hydrocephalus. Child's Nervous System. 2018; 34: 2195-2202.

[13] Liu X, Rivera SC, Faes L, Ferrante di Ruffano L, Yau C, Keane PA, et al. Reporting guidelines for clinical trials evaluating artificial intelligence interventions are needed. Nature Medicine. 2019; 25: 1467-1468.

[14] Paisan GM, Ding D, Starke RM, Crowley RW, Liu KC. Shunt-dependent hydrocephalus after aneurysmal subarachnoid hemorrhage: predictors and long-term functional outcomes. Neurosurgery. 2018; 83: 393-402.

[15] Lenski M, Biczok A, Huge V, Forbrig R, Briegel J, Tonn J, et al. Role of cerebrospinal fluid markers for predicting shunt-dependent hydrocephalus in patients with subarachnoid hemorrhage and external ventricular drain placement. World Neurosurgery. 2019; 121: e535-e542.

[16] Steiner T, Juvela S, Unterberg A, Jung C, Forsting M, Rinkel G. European Stroke Organization guidelines for the management of intracranial aneurysms and subarachnoid haemorrhage. Cerebrovascular Diseases. 2013; 35: 93-112.

[17] Cho W, Kim JE, Park SQ, Ko JK, Kim D, Park JC, et al. Korean clinical practice guidelines for aneurysmal subarachnoid hemorrhage. Journal of Korean Neurosurgical Society. 2018; 61: 127-166.

[18] Capion T, Lilja-Cyron A, Bartek J, Jr., Forsse A, Logallo N, Juhler $\mathrm{M}$, et al. Discontinuation of external ventricular drainage in patients with hydrocephalus following aneurysmal subarachnoid hemorrhagea scandinavian multi-institutional survey. Acta Neurochirurgica. 2020; 162: 1363-1370.

[19] Chung DY, Leslie-Mazwi TM, Patel AB, Rordorf GA. Management of external ventricular drains after subarachnoid hemorrhage: a multiinstitutional survey. Neurocritical Care. 2017; 26: 356-361.

[20] Chang SI, Tsai MD, Yen DH, Hsieh C. The clinical predictors of shunt-dependent hydrocephalus following aneurysmal subarachnoid hemorrhage. Turkish Neurosurgery. 2018; 28: 36-42.

[21] Gerner ST, Reichl J, Custal C, Brandner S, Eyüpoglu IY, Lücking H, et al. Long-term complications and influence on outcome in patients surviving spontaneous subarachnoid hemorrhage. Cerebrovascular Diseases. 2020; 49: $307-315$

[22] Delpirou Nouh C, Samkutty DG, Chandrashekhar S, Santucci JA, Ford $\mathrm{L}, \mathrm{Xu} \mathrm{C}$, et al. Management of aneurysmal subarachnoid hemorrhage: variation in clinical practice and unmet need for follow-up among survivors-a single-center perspective. World Neurosurgery. 2020; 139: e608-e617.

[23] Boswell S, Thorell W, Gogela S, Lyden E, Surdell D. Angiogram-negative subarachnoid hemorrhage: outcomes data and review of the literature. Journal of Stroke and Cerebrovascular Diseases. 2013; 22: 750-757.

[24] Sprenker C, Patel J, Camporesi E, Vasan R, Van Loveren H, Chen H, et al. Medical and neurologic complications of the current management strategy of angiographically negative nontraumatic subarachnoid hemorrhage patients. Journal of Critical Care. 2015; 30: 216.e7-216.11.

[25] Konczalla J, Schmitz J, Kashefiolasl S, Senft C, Seifert V, Platz J. Nonaneurysmal subarachnoid hemorrhage in 173 patients: a prospective study of long-term outcome. European Journal of Neurology. 2015; 22: 1329-1336.

[26] Walcott BP, Stapleton CJ, Koch MJ, Ogilvy CS. Diffuse patterns of nonaneurysmal subarachnoid hemorrhage originating from the Basal cisterns have predictable vasospasm rates similar to aneurysmal subarachnoid hemorrhage. Journal of Stroke and Cerebrovascular Diseases. 2015; 24 : 795-801.

[27] Coelho LGBSA, Costa JMD, Silva EIPA. Non-aneurysmal spontaneous subarachnoid hemorrhage: perimesencephalic versus nonperimesencephalic. Revista Brasileira De Terapia Intensiva. 2016; 28 : 141-146.

[28] Isaacs AM, Riva-Cambrin J, Yavin D, Hockley A, Pringsheim TM, Jette $\mathrm{N}$, et al. Age-specific global epidemiology of hydrocephalus: systematic review, metanalysis and global birth surveillance. PLoS ONE. 2018; 13 : e0204926.

[29] Garton T, Keep RF, Wilkinson DA, Strahle JM, Hua Y, Garton HJL, et al. Intraventricular hemorrhage: the role of blood components in secondary injury and hydrocephalus. Translational Stroke Research. 2016; 7: 447451.

[30] O'Kelly CJ, Kulkarni AV, Austin PC, Urbach D, Wallace MC. Shuntdependent hydrocephalus after aneurysmal subarachnoid hemorrhage: 
incidence, predictors, and revision rates. Journal of Neurosurgery. 2009; 111: 1029-1035.

[31] Kanev PM, Sheehan JM. Reflections on shunt infection. Pediatric Neurosurgery. 2003; 39: 285-290.

[32] Dewan MC, Rattani A, Mekary R, Glancz LJ, Yunusa I, Baticulon RE, et al. Global hydrocephalus epidemiology and incidence: systematic review and meta-analysis. Journal of Neurosurgery. 2018; 130: 1-15.

[33] Wessell AP, Kole MJ, Cannarsa G, Oliver J, Jindal G, Miller T, et al. A sustained systemic inflammatory response syndrome is associated with shunt-dependent hydrocephalus after aneurysmal subarachnoid hemorrhage. Journal of Neurosurgery. 2018; 130: 1-8.

[34] Yu H, Zhan R, Wen L, Shen J, Fan Z. The relationship between risk factors and prognostic factors in patients with shunt-dependent hydrocephalus after aneurysmal subarachnoid hemorrhage. The Journal of Craniofacial Surgery. 2014; 25: 902-906.

[35] Kim JH, Kim JH, Kang HI, Kim DR, Moon BG, Kim JS. Risk factors and preoperative risk scoring system for shunt-dependent hydrocephalus following aneurysmal subarachnoid hemorrhage. Journal of Korean Neurosurgical Society. 2019; 62: 643-648.

[36] Bae I, Yi H, Choi K, Chun H. Comparison of incidence and risk factors for shunt-dependent hydrocephalus in aneurysmal subarachnoid hemorrhage patients. Journal of Cerebrovascular and Endovascular Neurosurgery. 2014; 16: 78-84.

[37] Chan M, Alaraj A, Calderon M, Herrera SR, Gao W, Ruland S, et al. Prediction of ventriculoperitoneal shunt dependency in patients with aneurysmal subarachnoid hemorrhage. Journal of Neurosurgery. 2009; 110: 44-49.

[38] Wessell AP, Kole MJ, Cannarsa G, Oliver J, Jindal G, Miller T, et al. A sustained systemic inflammatory response syndrome is associated with shunt-dependent hydrocephalus after aneurysmal subarachnoid hemorrhage. Journal of Neurosurgery. 2019; 130: 1984-1991.

[39] Savarraj J, Parsha K, Hergenroeder G, Ahn S, Chang TR, Kim DH, et al. Early brain injury associated with systemic inflammation after subarachnoid hemorrhage. Neurocritical Care. 2018; 28: 203-211.

[40] Chen L, Zhang Q. Increased mean platelet volume is associated with poor outcome in patients with aneurysmal subarachnoid hemorrhage. World Neurosurgery. 2020; 137: e118-e125.

[41] Jabbarli R, Pierscianek D, RÖlz R, Reinhard M, Darkwah Oppong M, Scheiwe $\mathrm{C}$, et al. Gradual external ventricular drainage weaning reduces the risk of shunt dependency after aneurysmal subarachnoid hemorrhage: a pooled analysis. Operative Neurosurgery. 2018; 15: 498-504.

[42] Nakatsuka Y, Kawakita F, Yasuda R, Umeda Y, Toma N, Sakaida H, et al. Preventive effects of cilostazol against the development of shuntdependent hydrocephalus after subarachnoid hemorrhage. Journal of Neurosurgery. 2017; 127: 319-326.

[43] Han M, Won YD, Na MK, Kim CH, Kim JM, Ryu JI, et al. Association between possible osteoporosis and shunt-dependent hydrocephalus after subarachnoid hemorrhage. Stroke. 2018; 49: 1850-1858.

[44] Virta JJ, Satopää J, Luostarinen T, Raj R. One-year outcome after aneurysmal subarachnoid hemorrhage in elderly patients. World Neurosurgery. 2020; 143: e334-e343.

[45] Diesing D, Wolf S, Sommerfeld J, Sarrafzadeh A, Vajkoczy P, Dengler NF. A novel score to predict shunt dependency after aneurysmal subarachnoid hemorrhage. Journal of Neurosurgery. 2018; 128: 12731279.

[46] García S, Torné R, Hoyos JA, Rodríguez-Hernández A, Amaro S, Llull $\mathrm{L}$, et al. Quantitative versus qualitative blood amount assessment as a predictor for shunt-dependent hydrocephalus following aneurysmal subarachnoid hemorrhage. Journal of Neurosurgery. 2018; 131: 17431750.

[47] Adams H, Ban VS, Leinonen V, Aoun SG, Huttunen J, Saavalainen $\mathrm{T}$, et al. Risk of shunting after aneurysmal subarachnoid hemorrhage: a collaborative study and initiation of a consortium. Stroke. 2016; 47 : 2488-2496.

[48] Erixon HO, Sorteberg A, Sorteberg W, Eide PK. Predictors of shunt dependency after aneurysmal subarachnoid hemorrhage: results of a single-center clinical trial. Acta Neurochirurgica. 2014; 156: 2059-2069.

[49] Jeong TS, Yoo CJ, Kim WK, Yee GT, Kim EY, Kim MJ. Factors related to the development of shunt-dependent hydrocephalus following subarachnoid hemorrhage in the elderly. Turkish Neurosurgery. 2018; 28 :
226-233.

[50] Mijderwijk H, Fischer I, Zhivotovskaya A, Bostelmann R, Steiger $\mathrm{H}$, Cornelius JF, et al. Prognostic model for chronic shunt-dependent hydrocephalus after aneurysmal subarachnoid hemorrhage. World Neurosurgery. 2019; 124: e572-e579.

[51] Zaidi HA, Montoure A, Elhadi A, Nakaji P, McDougall CG, Albuquerque $\mathrm{FC}$, et al. Long-term functional outcomes and predictors of shunt-dependent hydrocephalus after treatment of ruptured intracranial aneurysms in the BRAT trial: revisiting the clip vs coil debate. Neurosurgery. 2015; 76: 608-613.

[52] Chung DY, Olson DM, John S, Mohamed W, Kumar MA, Thompson BB, et al. Evidence-based management of external ventricular drains. Current Neurology and Neuroscience Reports. 2019; 19: 94.

[53] Gupta R, Ascanio LC, Enriquez-Marulanda A, Griessenauer CJ, Chinnadurai A, Jhun $\mathrm{R}$, et al. Validation of a predictive scoring system for ventriculoperitoneal shunt insertion after aneurysmal subarachnoid hemorrhage. World Neurosurgery. 2018; 109: e210-e216.

[54] Walcott BP, Iorgulescu JB, Stapleton CJ, Kamel H. Incidence, timing, and predictors of delayed shunting for hydrocephalus after aneurysmal subarachnoid hemorrhage. Neurocritical Care. 2015; 23: 54-58.

[55] Hasan D, Vermeulen M, Wijdicks EF, Hijdra A, van Gijn J. Management problems in acute hydrocephalus after subarachnoid hemorrhage. Stroke. 1989; 20: 747-753.

[56] Park YK, Yi H, Choi K, Lee Y, Chun H, Kwon SM, et al. Predicting factors for shunt-dependent hydrocephalus in patients with aneurysmal subarachnoid hemorrhage. Acta Neurochirurgica. 2018; 160: 1407-1413.

[57] Chen S, Luo J, Reis C, Manaenko A, Zhang J. Hydrocephalus after subarachnoid hemorrhage: pathophysiology, diagnosis, and treatment. BioMed Research International. 2017; 2017: 8584753.

[58] Miller BA, Turan N, Chau M, Pradilla G. Inflammation, vasospasm, and brain injury after subarachnoid hemorrhage. BioMed Research International. 2014; 2014: 384342.

[59] Satomi J, Hadeishi H, Yoshida Y, Suzuki A, Nagahiro S. Histopathological findings in brains of patients who died in the acute stage of poorgrade subarachnoid hemorrhage. Neurologia Medico-Chirurgica. 2016; 56: 766-770.

[60] Klimo P, Kestle JRW, MacDonald JD, Schmidt RH. Marked reduction of cerebral vasospasm with lumbar drainage of cerebrospinal fluid after subarachnoid hemorrhage. Journal of Neurosurgery. 2004; 100: 215-224.

[61] Carare RO, Bernardes-Silva M, Newman TA, Page AM, Nicoll JAR, Perry VH, et al. Solutes, but not cells, drain from the brain parenchyma along basement membranes of capillaries and arteries: significance for cerebral amyloid angiopathy and neuroimmunology. Neuropathology and Applied Neurobiology. 2008; 34: 131-144.

[62] Golanov EV, Bovshik EI, Wong KK, Pautler RG, Foster CH, Federley $\mathrm{RG}$, et al. Subarachnoid hemorrhage-induced block of cerebrospinal fluid flow: role of brain coagulation factor III (tissue factor). Journal of Cerebral Blood Flow and Metabolism. 2018; 38: 793-808.

[63] Close LN, Zanaty M, Kirby P, Dlouhy BJ. Acute hydrocephalus resulting from neuromyelitis optica: a case report and review of the literature. World Neurosurgery. 2019; 129: 367-371.

[64] Bloch O, Papadopoulos MC, Manley GT, Verkman AS. Aquaporin-4 gene deletion in mice increases focal edema associated with staphylococcal brain abscess. Journal of Neurochemistry. 2005; 95: 254-262.

[65] Lucke-Wold BP, Logsdon AF, Manoranjan B, Turner RC, McConnell $\mathrm{E}$, Vates GE, et al. Aneurysmal subarachnoid hemorrhage and neuroinflammation: a comprehensive review. International Journal of Molecular Sciences. 2016; 17: 497.

[66] de Oliveira Manoel AL, Macdonald RL. Neuroinflammation as a target for intervention in subarachnoid hemorrhage. Frontiers in Neurology. 2018; 9: 292.

[67] Macdonald RL, Marton LS, Andrus PK, Hall ED, Johns L, Sajdak M. Time course of production of hydroxyl free radical after subarachnoid hemorrhage in dogs. Life Sciences. 2004; 75: 979-989.

[68] Hua C, Zhao G. Biomarkers in adult posthemorrhagic hydrocephalus. International Journal of Stroke. 2017; 12: 574-579.

[69] Tombini M, Squitti R, Cacciapaglia F, Ventriglia M, Assenza G, Benvenga A, et al. Inflammation and iron metabolism in adult patients with epilepsy: does a link exist? Epilepsy Research. 2013; 107: 244-252.

[70] Mahaney KB, Buddhala C, Paturu M, Morales D, Limbrick DD, 
Strahle JM. Intraventricular hemorrhage clearance in human neonatal cerebrospinal fluid: associations with hydrocephalus. Stroke. 2020; 51: 1712-1719.

[71] Zhang Y, Zheng S, Shang-Guan H, Kang D, Chen G, Yao P. Lower iron levels predict acute hydrocephalus following aneurysmal subarachnoid hemorrhage. World Neurosurgery. 2019; 126: e907-e913.

[72] Sokół B, Woźniak A, Jankowski R, Jurga S, Wąsik N, Shahid H, et al. HMGB1 level in cerebrospinal fluid as a marker of treatment outcome in patients with acute hydrocephalus following aneurysmal subarachnoid hemorrhage. Journal of Stroke and Cerebrovascular Diseases. 2015; 24 : 1897-1904.

[73] Sun Q, Wu W, Hu Y, Li H, Zhang D, Li S, et al. Early release of highmobility group box 1 (HMGB1) from neurons in experimental subarachnoid hemorrhage in vivo and in vitro. Journal of Neuroinflammation. 2014; 11: 106.

[74] Macdonald RL, Schweizer TA. Spontaneous subarachnoid haemorrhage. The Lancet. 2017; 389: 655-666.

[75] Chaudhry SR, Hafez A, Rezai Jahromi B, Kinfe TM, Lamprecht A, Niemelä M, et al. Role of damage associated molecular pattern molecules (DAMPs) in aneurysmal subarachnoid hemorrhage (aSAH). International Journal of Molecular Sciences. 2018; 19: 2035.

[76] Muhammad S, Chaudhry SR, Kahlert UD, Lehecka M, Korja M, Niemelä M, et al. Targeting high mobility group box 1 in subarachnoid hemorrhage: a systematic review. International Journal of Molecular Sciences. 2020; 21: 2709 .

[77] Balusu S, Van Wonterghem E, De Rycke R, Raemdonck K, Stremersch $\mathrm{S}$, Gevaert $\mathrm{K}$, et al. Identification of a novel mechanism of bloodbrain communication during peripheral inflammation via choroid plexusderived extracellular vesicles. EMBO Molecular Medicine. 2016; 8: 1162-1183.

[78] Karimy JK, Zhang J, Kurland DB, Theriault BC, Duran D, Stokum JA, et al. Inflammation-dependent cerebrospinal fluid hypersecretion by the choroid plexus epithelium in posthemorrhagic hydrocephalus. Nature Medicine. 2017; 23: 997-1003.

[79] Lv SY, Wu Q, Liu JP, Shao J, Wen LL, Xue J, et al. Levels of interleukin$1 \beta$, interleukin-18, and tumor necrosis factor- $\alpha$ in cerebrospinal fluid of aneurysmal subarachnoid hemorrhage patients may be predictors of early brain injury and clinical prognosis. World Neurosurg. 2018; 111: e362e373.

[80] Chaudhry SR, Stoffel-Wagner B, Kinfe TM, Güresir E, Vatter H, Dietrich D, et al. Elevated systemic IL-6 levels in patients with aneurysmal subarachnoid hemorrhage is an unspecific marker for postSAH complications. International Journal of Molecular Sciences. 2017; 18: 2580.

[81] Chaudhry SR, Güresir E, Vatter H, Kinfe TM, Dietrich D, Lamprecht A, et al. Aneurysmal subarachnoid hemorrhage lead to systemic upregulation of IL-23/IL-17 inflammatory axis. Cytokine. 2018; 97: 96-103.

[82] Wessell AP, Kole MJ, Cannarsa G, Oliver J, Jindal G, Miller T, et al. A sustained systemic inflammatory response syndrome is associated with shunt-dependent hydrocephalus after aneurysmal subarachnoid hemorrhage. Journal of Neurosurgery. 2018; 130: 1-8.

[83] Chaudhry SR, Kahlert UD, Kinfe TM, Lamprecht A, Niemelä M, Hänggi D, et al. Elevated systemic IL-10 levels indicate immunodepression leading to nosocomial infections after aneurysmal subarachnoid hemorrhage (SAH) in patients. International Journal of Molecular Sciences. 2020; 21 : 1569.

[84] Mittal SK, Cho K, Ishido S, Roche PA. Interleukin 10 (IL-10)-mediated immunosuppression: MARCH-i induction regulates antigen presentation by macrophages but not dendritic cells. The Journal of Biological Chemistry. 2015; 290: 27158-27167.

[85] Wang K, Tang S, Lee J, Li Y, Huang Y, Yang W, et al. Cerebrospinal fluid high mobility group box 1 is associated with neuronal death in subarachnoid hemorrhage. Journal of Cerebral Blood Flow and Metabolism. 2017; 37: 435-443.

[86] Zhan C, Xiao G, Zhang X, Chen X, Zhang Z, Liu J. Decreased MiR30a promotes TGF- $\beta 1$-mediated arachnoid fibrosis in post-hemorrhagic hydrocephalus. Translational Neuroscience. 2020; 11: 60-74.

[87] Shim JW, Sandlund J, Hameed MQ, Blazer-Yost B, Zhou FC, Klagsbrun $\mathrm{M}$, et al. Excess HB-EGF, which promotes VEGF signaling, leads to hydrocephalus. Scientific Reports. 2016; 6: 26794.
[88] Chen W, Ten Dijke P. Immunoregulation by members of the TGF $\beta$ superfamily. Nature Reviews Immunology. 2016; 16: 723-740.

[89] Douglas MR, Daniel M, Lagord C, Akinwunmi J, Jackowski A, Cooper C, et al. High CSF transforming growth factor beta levels after subarachnoid haemorrhage: association with chronic communicating hydrocephalus. Journal of Neurology, Neurosurgery, and Psychiatry. 2009; 80: 545-550.

[90] Yan H, Chen Y, Li L, Jiang J, Wu G, Zuo Y, et al. Decorin alleviated chronic hydrocephalus via inhibiting TGF- $\beta 1 / \mathrm{Smad} / \mathrm{CTGF}$ pathway after subarachnoid hemorrhage in rats. Brain Research. 2016; 1630: 241-253.

[91] Botfield H, Gonzalez AM, Abdullah O, Skjolding AD, Berry M, McAllister JP, et al. Decorin prevents the development of juvenile communicating hydrocephalus. Brain. 2013; 136: 2842-2858.

[92] Chen H, Chen L, Xie D, Niu J. Protective effects of transforming growth factor- $\beta 1$ knockdown in human umbilical cord mesenchymal stem cells against subarachnoid hemorrhage in a rat model. Cerebrovascular Diseases. 2020; 49: 79-87.

[93] Tan Q, Chen Q, Feng Z, Shi X, Tang J, Tao Y, et al. Cannabinoid receptor 2 activation restricts fibrosis and alleviates hydrocephalus after intraventricular hemorrhage. Brain Research. 2017; 1654: 24-33.

[94] Shim JW, Madsen JR. VEGF signaling in neurological disorders. International Journal of Molecular Sciences. 2018; 19: 275.

[95] Asami A, Kurganov E, Miyata S. Proliferation of endothelial cells in the choroid plexus of normal and hydrocephalic mice. Journal of Chemical Neuroanatomy. 2020; 106: 101796.

[96] Reeson P, Tennant KA, Gerrow K, Wang J, Weiser Novak S, Thompson $\mathrm{K}$, et al. Delayed inhibition of VEGF signaling after stroke attenuates blood-brain barrier breakdown and improves functional recovery in a comorbidity-dependent manner. Journal of Neuroscience. 2015; 35 : 5128-5143.

[97] Naureen I, Waheed KAI, Rathore AW, Victor S, Mallucci C, Goodden JR, et al. Fingerprint changes in CSF composition associated with different aetiologies in human neonatal hydrocephalus: inflammatory cytokines. Child's Nervous System. 2014; 30: 1155-1164.

[98] Yoshimura S, Morishita R, Hayashi K, Kokuzawa J, Aoki M, Matsumoto $\mathrm{K}$, et al. Gene transfer of hepatocyte growth factor to subarachnoid space in cerebral hypoperfusion model. Hypertension. 2002; 39: 1028-1034.

[99] Feng Z, Liu S, Chen Q, Tan Q, Xian J, Feng H, et al. UPA alleviates kaolin-induced hydrocephalus by promoting the release and activation of hepatocyte growth factor in rats. Neuroscience Letters. 2020; 731: 135011.

[100] Gholampour S. FSI simulation of CSF hydrodynamic changes in a large population of non-communicating hydrocephalus patients during treatment process with regard to their clinical symptoms. PLoS ONE. 2018; 13: e0196216.

[101] Guillerman RP. Infant craniospinal ultrasonography: beyond hemorrhage and hydrocephalus. Seminars in Ultrasound, CT, and MR. 2010; 31: 71-85

[102] Eymann R. Clinical symptoms of hydrocephalus. Der Radiologe. 2012; 52: 807-812. (In German)

[103] Langner S, Fleck S, Baldauf J, Mensel B, Kühn JP, Kirsch M. Diagnosis and differential diagnosis of hydrocephalus in adults. Fortschritte Auf Dem Gebiete Der Rontgenstrahlen Und Der Nuklearmedizin. 2017; 189 : 728-739.

[104] Kartal MG, Ocakoglu G, Algin O. Feasibility of 3-dimensional sampling perfection with application optimized contrast sequence in the evaluation of patients with hydrocephalus. Journal of Computer Assisted Tomography. 2015; 39: 321-328.

[105] Relkin N, Marmarou A, Klinge P, Bergsneider M, Black PM. Diagnosing idiopathic normal-pressure hydrocephalus. Neurosurgery. 2005; 57: S4S16.

[106] Kartal MG, Algin O. Evaluation of hydrocephalus and other cerebrospinal fluid disorders with MRI: an update. Insights into Imaging. 2014; 5: 531-541.

[107] Beaumont TL, Limbrick DD, Rich KM, Wippold FJ, Dacey RG. Natural history of colloid cysts of the third ventricle. Journal of Neurosurgery. 2016; 125: 1420-1430.

[108] Langner S, Buelow R, Fleck S, Angermaier A, Kirsch M. Management of intracranial incidental findings on brain MRI. Fortschritte Auf Dem Gebiete Der Rontgenstrahlen Und Der Nuklearmedizin. 2016; 188: 1123 1133. 
[109] Jaraj D, Rabiei K, Marlow T, Jensen C, Skoog I, Wikkelsø C. Estimated ventricle size using Evans index: reference values from a populationbased sample. European Journal of Neurology. 2017; 24: 468-474.

[110] Missori P, Rughetti A, Peschillo S, Gualdi G, Di Biasi C, Nofroni I, et $a l$. In normal aging ventricular system never attains pathological values of Evans' index. Oncotarget. 2016; 7: 11860-11863.

[111] Brix MK, Westman E, Simmons A, Ringstad GA, Eide PK, WagnerLarsen $\mathrm{K}$, et al. The Evans' index revisited: new cut-off levels for use in radiological assessment of ventricular enlargement in the elderly. European Journal of Radiology. 2017; 95: 28-32.

[112] Gunes A, Oncel IH, Gunes SO, Birbilen AZ, Hanalioglu S. Use of computed tomography and diffusion weighted imaging in children with ventricular shunt. Child's Nervous System. 2019; 35: 477-486.

[113] Ohana O, Soffer S, Zimlichman E, Klang E. Overuse of CT and MRI in paediatric emergency departments. The British Journal of Radiology. 2018; 91: 20170434.

[114] Narayan AK, Tekes A, Greene A, Mahesh M, Jackson EM, Huisman TAGM, et al. Radiation dose reduction in children with hydrocephalus using ultrafast brain MRI. Journal of the American College of Radiology. 2019; 16: 1173-1176.

[115] Marchese RF, Schwartz ES, Heuer GG, Lavelle J, Huh JW, Bell LM, et al. Reduced radiation in children presenting to the ed with suspected ventricular shunt complication. Pediatrics. 2017; 139: e20162431.

[116] Wymer DT, Patel KP, Burke WF, Bhatia VK. Phase-contrast MRI: physics, techniques, and clinical applications. RadioGraphics. 2020; 40: $122-140$.

[117] Bradley WG, Kortman KE, Burgoyne B. Flowing cerebrospinal fluid in normal and hydrocephalic states: appearance on MR images. Radiology. 1986; 159: 611-616.

[118] Bargalló N, Olondo L, Garcia AI, Capurro S, Caral L, Rumia J. Functional analysis of third ventriculostomy patency by quantification of CSF stroke volume by using cine phase-contrast MR imaging. American Journal of Neuroradiology. 2005; 26: 2514-2521.

[119] Hosny A, Parmar C, Quackenbush J, Schwartz LH, Aerts HJWL. Artificial intelligence in radiology. Nature Reviews Cancer. 2018; 18: 500-510.

[120] Ibrahim GM, Macdonald RL. The network topology of aneurysmal subarachnoid haemorrhage. Journal of Neurology, Neurosurgery \& Psychiatry. 2015; 86: 895-901.

[121] Duan W, Zhang J, Zhang L, Lin Z, Chen Y, Hao X, et al. Evaluation of an artificial intelligent hydrocephalus diagnosis model based on transfer learning. Medicine. 2020; 99: e21229.

[122] Russakovsky O, Deng J, Su H, Krause J, Satheesh S, Ma S, et al. ImageNet large scale visual recognition challenge. International Journal of Computer Vision. 2015; 115: 211-252.

[123] Komura D, Ishikawa S. Machine learning approaches for pathologic diagnosis. Virchows Archiv. 2019; 475: 131-138.

[124] Klimont M, Flieger M, Rzeszutek J, Stachera J, Zakrzewska A, JończykPotoczna K. Automated ventricular system segmentation in paediatric patients treated for hydrocephalus using deep learning methods. BioMed Research International. 2019; 2019: 3059170.

[125] Rasmussen MK, Mestre H, Nedergaard M. The glymphatic pathway in neurological disorders. The Lancet Neurology. 2018; 17: 1016-1024.

[126] Gao F, Zheng M, Hua Y, Keep RF, Xi G. Acetazolamide attenuates thrombin-induced hydrocephalus. Acta Neurochirurgica Supplement. 2016; 121: 373-377.

[127] Owler BK, Pitham T, Wang D. Aquaporins: relevance to cerebrospinal fluid physiology and therapeutic potential in hydrocephalus. Cerebrospinal Fluid Research. 2010; 7 : 15.

[128] Trillo-Contreras JL, Ramírez-Lorca R, Hiraldo-González L, SánchezGomar I, Galán-Cobo A, Suárez-Luna N, et al. Combined effects of aquaporin-4 and hypoxia produce age-related hydrocephalus. Biochimica et Biophysica Acta Molecular Basis of Disease. 2018; 1864: 3515-3526.

[129] Carrion E, Hertzog JH, Medlock MD, Hauser GJ, Dalton HJ. Use of acetazolamide to decrease cerebrospinal fluid production in chronically ventilated patients with ventriculopleural shunts. Archives of Disease in Childhood. 2001; 84: 68-71.

[130] McCarthy KD, Reed DJ. The effect of acetazolamide and furosemide on cerebrospinal fluid production and choroid plexus carbonic anhydrase activity. The Journal of Pharmacology and Experimental Therapeutics.
1974; 189: 194-201.

[131] Uldall M, Botfield H, Jansen-Olesen I, Sinclair A, Jensen R. Acetazolamide lowers intracranial pressure and modulates the cerebrospinal fluid secretion pathway in healthy rats. Neuroscience Letters. 2017; 645: 3339.

[132] Bin K, Shi-Peng Z. Acetazolamide inhibits aquaporin-1 expression and colon cancer xenograft tumor growth. Hepato-Gastroenterology. 2011; 58: 1502-1506.

[133] Abir-Awan M, Kitchen P, Salman MM, Conner MT, Conner AC, Bill RM. Inhibitors of mammalian aquaporin water channels. International Journal of Molecular Sciences. 2019; 20: 1589.

[134] Libenson MH, Kaye EM, Rosman NP, Gilmore HE. Acetazolamide and furosemide for posthemorrhagic hydrocephalus of the newborn. Pediatric Neurology. 1999; 20: 185-191.

[135] Kennedy CR, Ayers S, Campbell MJ, Elbourne D, Hope P, Johnson A. Randomized, controlled trial of acetazolamide and furosemide in posthemorrhagic ventricular dilation in infancy: follow-up at 1 year. Pediatrics. 2001; 108: 597-607.

[136] International randomised controlled trial of acetazolamide and furosemide in posthaemorrhagic ventricular dilatation in infancy. International PHVD Drug Trial Group. Lancet. 1998; 352: 433-440.

[137] Mazzola CA, Choudhri AF, Auguste KI, Limbrick DD, Rogido M, Mitchell L, et al. Pediatric hydrocephalus: systematic literature review and evidence-based guidelines. Part 2: management of posthemorrhagic hydrocephalus in premature infants. Journal of Neurosurgery. 2014; 14: 8-23.

[138] Suryaningtyas W, Arifin M, Rantam FA, Bajamal AH, Dahlan YP, Dewa Gede Ugrasena I, et al. Erythropoietin protects the subventricular zone and inhibits reactive astrogliosis in kaolin-induced hydrocephalic rats. Child's Nervous System. 2019; 35: 469-476.

[139] Sporrborn JL, Knudsen GB, Sølling M, Seierøe K, Farre A, Lindhardt $\mathrm{B} \varnothing$, et al. Brain ventricular dimensions and relationship to outcome in adult patients with bacterial meningitis. BMC Infectious Diseases. 2015; 15: 367.

[140] Thwaites GE, Macmullen-Price J, Chau TTH, Phuong Mai P, Dung NT, Simmons CP, et al. Serial MRI to determine the effect of dexamethasone on the cerebral pathology of tuberculous meningitis: an observational study. The Lancet Neurology. 2007; 6: 230-236.

[141] Shah I, Meshram L. High dose versus low dose steroids in children with tuberculous meningitis. Journal of Clinical Neuroscience. 2014; 21: 761764.

[142] Toma N, Imanaka-Yoshida K, Takeuchi T, Matsushima S, Iwata H, Yoshida $\mathrm{T}$, et al. Tenascin-C-coated platinum coils for acceleration of organization of cavities and reduction of lumen size in a rat aneurysm model. Journal of Neurosurgery. 2005; 103: 681-686.

[143] Sajanti J, Heikkinen E, Majamaa K. Rapid induction of meningeal collagen synthesis in the cerebral cisternal and ventricular compartments after subarachnoid hemorrhage. Acta Neurochirurgica. 2008; 104: 179182.

[144] Cho O, Jang Y, Park K, Heo T. Beneficial anti-inflammatory effects of combined rosuvastatin and cilostazol in a TNF-driven inflammatory model. Pharmacological Reports. 2019; 71: 266-271.

[145] Yeh P, Huang Y, Chang S, Wang L, Yang C, Yang W, et al. Cilostazol attenuates retinal oxidative stress and inflammation in a streptozotocininduced diabetic animal model. Current Eye Research. 2019; 44: 294302.

[146] Melo JRT, Di Rocco F, Bourgeois M, Puget S, Blauwblomme T, Sainte-Rose C, et al. Surgical options for treatment of traumatic subdural hematomas in children younger than 2 years of age. Journal of Neurosurgery: Pediatrics. 2014; 13: 456-461.

[147] Ilic I, Schuss P, Borger V, Hadjiathanasiou A, Vatter H, Fimmers R, et al. Ventriculostomy with subsequent ventriculoperitoneal shunt placement after subarachnoid hemorrhage: the effect of implantation site on postoperative complications-a single-center series. Acta Neurochirurgica. 2020; 162: 1831-1836.

[148] Bjornson A, Tapply I, Nabbanja E, Lalou A, Czosnyka M, Czosnyka $\mathrm{Z}$, et al. Ventriculo-peritoneal shunting is a safe and effective treatment for idiopathic intracranial hypertension. British Journal of Neurosurgery. 2019; 33: 62-70

[149] Mallucci CL, Jenkinson MD, Conroy EJ, Hartley JC, Brown M, Dalton 
$\mathrm{J}$, et al. Antibiotic or silver versus standard ventriculoperitoneal shunts (BASICS): a multicentre, single-blinded, randomised trial and economic evaluation. Lancet. 2019; 394: 1530-1539.

[150] Zhu X. The hemorrhage risk of prophylactic external ventricular drain insertion in aneurysmal subarachnoid hemorrhage patients requiring endovascular aneurysm treatment: a systematic review and metaanalysis. Journal of Neurosurgical Sciences. 2017; 61: 53-63.

[151] Liang C, Yang L, Guo S. Serial lumbar puncture reduces cerebrospinal fluid (CSF) infection during removal of hemorrhagic CSF in aneurysmal subarachnoid hemorrhage after endovascular coiling. The Journal of Biomedical Research. 2018; 32: 305-310.

[152] Tan C, Wang X, Wang Y, Wang C, Tang Z, Zhang Z, et al. The pathogenesis based on the glymphatic system, diagnosis, and treatment of idiopathic normal pressure hydrocephalus. Clinical Interventions in Aging. 2021; 16: 139-153.

[153] Alqaim M, Cosar E, Crawford AS, Robichaud DI, Walz JM, Schanzer A, et al. Lumbar drain complications in patients undergoing fenestrated or branched endovascular aortic aneurysm repair: development of an institutional protocol for lumbar drain management. Journal of Vascular Surgery. 2020; 72: 1576-1583.

[154] Souweidane MM. Endoscopic management of pediatric brain tumors. Neurosurgical Focus. 2005; 18: E1.

[155] O’Brien DF, Hayhurst C, Pizer B, Mallucci CL. Outcomes in patients undergoing single-trajectory endoscopic third ventriculostomy and endoscopic biopsy for midline tumors presenting with obstructive hydrocephalus. Journal of Neurosurgery. 2006; 105: 219-226.

[156] Etus V, Ceylan S. Success of endoscopic third ventriculostomy in children less than 2 years of age. Neurosurgical Review. 2005; 28: 284288 .

[157] Ascanio LC, Gupta R, Adeeb N, Moore JM, Griessenauer CJ, Mayeku $\mathrm{J}$, et al. Relationship between external ventricular drain clamp trials and ventriculoperitoneal shunt insertion following nontraumatic subarachnoid hemorrhage: a single-center study. Journal of Neurosurgery. 2018; 130: 956-962.

[158] Akinduro OO, Vivas-Buitrago TG, Haranhalli N, Ganaha S, Mbabuike N, Turnbull MT, et al. Predictors of ventriculoperitoneal shunting following subarachnoid hemorrhage treated with external ventricular drainage. Neurocritical Care. 2020; 32: 755-764.

[159] Kamenova M, Croci D, Guzman R, Mariani L, Soleman J. Low-dose acetylsalicylic acid and bleeding risks with ventriculoperitoneal shunt placement. Neurosurgical Focus. 2016; 41: E4.

[160] Wajd NA-H, Thomas JW, Zarina SA, Ryan PB, Kelly JB, Tannaz G, et al. Gastrostomy tube placement increases the risk of ventriculoperitoneal shunt infection: a multiinstitutional study. Journal of Neurosurgery. 2018; 131: 1-6.

[161] Zhang Y, Zhu X, Zhao J, Hou K, Gao X, Sun Y, et al. Ventriculoperitoneal shunting surgery with open distal shunt catheter placement in the treatment of hydrocephalus. Cell Biochemistry and Biophysics. 2015; 73: 533-536.

[162] Rumalla K, Smith KA, Arnold PM, Mittal MK. Subarachnoid hemorrhage and readmissions: national rates, causes, risk factors, and outcomes in 16,001 hospitalized patients. World Neurosurgery. 2018; 110: e100e111.

[163] Dasenbrock HH, Smith TR, Rudy RF, Gormley WB, Aziz-Sultan MA, $\mathrm{Du}$ R. Reoperation and readmission after clipping of an unruptured intracranial aneurysm: a National Surgical Quality Improvement Program analysis. Journal of Neurosurgery. 2018; 128: 756-767.

[164] Dasenbrock HH, Angriman F, Smith TR, Gormley WB, Frerichs KU, Aziz-Sultan MA, et al. Readmission after aneurysmal subarachnoid hemorrhage: a nationwide readmission database analysis. Stroke. 2017; 48: 2383-2390.

[165] Wang Y, Gao Y, Lu M, Liu Y. Long-term functional prognosis of patients with aneurysmal subarachnoid hemorrhage treated with rehabilitation combined with hyperbaric oxygen: case-series study. Medicine. 2020; 99: e18748.

[166] Bateman RM, Sharpe MD, Jagger JE, Ellis CG, Solé-Violán J, LópezRodríguez M, et al. 36th International Symposium on Intensive Care and Emergency Medicine: Brussels, Belgium. 15-18 March 2016. Critical Care. 2016; 20: 94.

[167] Karic T, Røe C, Nordenmark TH, Becker F, Sorteberg W, Sorteberg A. Effect of early mobilization and rehabilitation on complications in aneurysmal subarachnoid hemorrhage. Journal of Neurosurgery. 2017; 126: $518-526$

[168] Juvela S, Kaste M, Hillbom M. The effects of earlier surgery and shorter bedrest on the outcome in patients with subarachnoid haemorrhage. Journal of Neurology, Neurosurgery, and Psychiatry. 1989; 52: 776-777.

[169] Reijmer YD, van den Heerik MS, Heinen R, Leemans A, Hendrikse J, de Vis JB, et al. Microstructural white matter abnormalities and cognitive impairment after aneurysmal subarachnoid hemorrhage. Stroke. 2018; 49: 2040-2045.

[170] Lorber J. Isosorbide in the medical treatment of infantile hydrocephalus. Journal of Neurosurgery. 1973; 39: 702-711.

[171] Lackner P, Beer R, Broessner G, Helbok R, Galiano K, Pleifer C, et al. Efficacy of silver nanoparticles-impregnated external ventricular drain catheters in patients with acute occlusive hydrocephalus. Neurocritical Care. 2008; 8: 360-365.

[172] Tuettenberg J, Czabanka M, Horn P, Woitzik J, Barth M, Thomé C, et al. Clinical evaluation of the safety and efficacy of lumbar cerebrospinal fluid drainage for the treatment of refractory increased intracranial pressure. Journal of Neurosurgery. 2009; 110: 1200-1208.

[173] Sufianov AA, Sufianova GZ, Iakimov IA. Endoscopic third ventriculostomy in patients younger than 2 years: outcome analysis of 41 hydrocephalus cases. Journal of Neurosurgery. Pediatrics. 2010; 5: 392401.

[174] Murad A, Ghostine S, Colohan ART. Role of controlled lumbar CSF drainage for ICP control in aneurysmal SAH. Acta Neurochirurgica. 2011; 110: 183-187.

[175] Pinto FC, Saad F, Oliveira MF, Pereira RM, Miranda FL, Tornai JB, et al. Role of endoscopic third ventriculostomy and ventriculoperitoneal shunt in idiopathic normal pressure hydrocephalus: preliminary results of a randomized clinical trial. Neurosurgery. 2013; 72: 845-853; discussion 853-844

[176] Sun C, Du H, Yin L, He M, Tian Y, Li H. Choice for the removal of bloody cerebrospinal fluid in postcoiling aneurysmal subarachnoid hemorrhage: external ventricular drainage or lumbar drainage? Turkish Neurosurgery. 2014; 24: 737-744.

[177] Kulkarni AV, Riva-Cambrin J, Rozzelle CJ, Naftel RP, Alvey JS, Reeder RW, et al. Endoscopic third ventriculostomy and choroid plexus cauterization in infant hydrocephalus: a prospective study by the Hydrocephalus Clinical Research Network. Journal of Neurosurgery Pediatrics. 2018; 21: 214-223.

How to cite this article: Yu-Chang Wang, Xiao-Qiang Wang, Chang-Wu Tan, Chuan-Sen Wang, Zhi Tang, Zhi-Ping Zhang. Hydrocephalus after aneurysmal subarachnoid hemorrhage: Epidemiology, Pathogenesis, Diagnosis, and Management. Signa Vitae. 2021;17(4):4-17. doi:10.22514/sv.2021.021. 